\title{
Preliminary study on in vitro shoot culture of Hibiscus coddii subsp. barnardii, an indigenous South African flowering plant
}

\author{
Helena Jacoba du Plessis ${ }^{1 *}$ (D), Roumiana Vassileva Nikolova ${ }^{1}$ (D), Bronwyn Anne Egan ${ }^{1}$ (D), Riana Kleynhans ${ }^{1}$ (D) \\ ${ }^{1}$ University of Limpopo, Sovenga, South Africa.
}

\begin{abstract}
In vivo and in vitro grown plants of Hibiscus coddii subsp. barnardii were used as explant source for establishment of in vitro cultures. Nodal shoot explants derived from in vivo grown plants, both naturally and under controlled environmental conditions, showed high sensitivity to the surface disinfection treatment and poor survival in in vitro culture. In vitro grown seedlings proved successful as aseptic source of apical and basal shoot explants to establish contamination-free in vitro cultures. Sprouting of axillary buds was observed on $90 \%$ of apical shoot explants after four weeks of culture on full strength, plant growth regulator (PGR)-free Murashige and Skoog (MS) medium. However, further proliferation of short shoots, limited to the bud sprout at the explant base, occurred on only $50 \%$ of these explants. In contrast, all basal shoot explants attained 3-5 single primary axillary shoots (30-40 mm in length) while a clump of short $(5-10 \mathrm{~mm})$ shoots also formed at the base in $60 \%$ of these explants. In both explant types, addition of $0.25-1 \mathrm{mg} \mathrm{L}^{-1} 6$-Benzylaminopurine (BAP) to the MS medium resulted in a low frequency (10\%-60\%) of explants with short shoots $(5-10 \mathrm{~mm})$ that showed no further elongation. Moreover, explants cultured in the presence of BAP showed a high frequency of callus formation (up to $90 \%$ ) and low survival (20\%-60\%). A lower frequency of callus formation (30\%- $40 \%)$ and higher survival (90\%-100\%) of both explant types occurred on BAP-free medium. Further subculturing of primary and secondary axillary shoots onto fresh MS medium (with and without BAP) did not improve shoot multiplication. Regenerated plantlets from PGR-free MS medium were successfully acclimatized and hardened-off.
\end{abstract}

Keywords: Hibiscus coddii subsp. barnardii; explant source; in vitro seedlings; surface disinfection; tissue culture; 6-Benzylaminopurine.

\begin{abstract}
Resumo
Estabelecimento in vitro por brotações de Hibiscus coddii subsp. barnardii, uma espécie florífera nativa da África do Sul Hibiscus coddii subsp. barnardii é uma atraente espécie endêmica sul-africana, com uma distribuição limitada e restrições na colheita de plantas, sendo necessário um protocolo de cultivo in vitro para assegurar o estabelecimento contínuo ex vitro dessas plantas. As plantas cultivadas in vivo e in vitro foram utilizadas como fonte de explante para o estabelecimento de culturas in vitro. Os explantes de segmentos nodais derivados de plantas in vivo, tanto naturalmente como sob condições ambientais controladas, mostraram uma elevada sensibilidade aos tratamentos de desinfestação da superfície e uma baixa sobrevivência no cultivo in vitro. As plântulas cultivadas in vitro apresentaram sucesso como fonte asséptica de explantes de brotações apicais e basais para o estabelecimento de culturas in vitro sem contaminação. As brotações de gemas axilares (90-100\%) foram observadas tanto em explantes apicais como basais, após quatro semanas em meio de cultura Murashige e Skoog (MS), força total e sem reguladores de crescimento. Pequenas brotações ocorreram na base de 50\% dos explantes dos segmentos apicais. Em contraste, em todos os explantes de segmentos basais, formaram-se 3-5 brotações axilares primárias (30-40 $\mathrm{mm}$ de comprimento), enquanto que pequenas brotações curtas $(5-10 \mathrm{~mm})$ também se formaram na base em alguns desses explantes. Em ambos os tipos de explantes, a adição de 0,25-1 mg L-1 de 6-Benzilaminopurina (BAP) ao meio MS resultou em baixas frequências (10\%-60\%) de explantes com brotações menores (5-10 mm). Além disso, os explantes cultivados na presença de BAP mostraram alta frequência de formação de calos (até $90 \%$ ) e baixa sobrevivência (20\%-60\%). Menor frequência de formação de calos (30\%-40\%) e maior sobrevivência (90\%-100\%) ocorreram em ambos os tipos de explantes em meio de cultura sem BAP. Posteriormente, o subcultivo de brotações axilares primárias e secundárias em novo meio de cultura MS (com e sem BAP) não melhorou a multiplicação de brotos. Plantas regeneradas em meio de cultura MS sem reguladores de crescimento foram aclimatizadas com sucesso e estabelecidas em estufa.
\end{abstract}

Palavras-chave: assepsia; brotação axilar; calos; explante; micropropagação.

*Corresponding author: helena.duplessis@ul.ac.za 


\section{Introduction}

Hibiscus coddii Exell subsp. barnardii (Exell) Leistner \& P.J.D. Winter (family Malvaceae) is an indigenous and endemic flowering plant from drought-prone areas in South Africa that has potential as ornamental plant. However, reliable propagation methods for this plant are needed for horticultural and conservation purposes. Our previous studies have shown that the plant can be successfully propagated in vivo and in vitro by seeds (Du Plessis et al., 2019; Du Plessis et al., 2020), although only one plant per seed is produced, resulting in low regeneration efficiency. In vitro micropropagation offers the potential to produce a large number of plants from one aseptic explant in a short period of time (Chen, 2016).

Shoot culture is the most commonly used micropropagation technique for multiplication and plant regeneration (Davies et al., 2017; Debnath and Arigundam, 2020), and was used in the micropropagation of several Hibiscus species using different explant sources. Mature plants of Hibiscus moscheutos and Hibiscus rosa-sinensis, growing naturally or cultivated in a greenhouse, were used as source of nodal explants for shoot culture after surface disinfection of the plant material (Christensen et al., 2008; Manokari et al., 2016; Lobodina et al., 2020). However, in most instances, in vitro germinated seedlings of Hibiscus species served as aseptic explant source for shoot culture. Explants such as shoot apices, cotyledons, cotyledonary petioles, hypocotyls, leaves and nodal stem segments obtained from these seedlings were used for initiation and multiplication of shoots, mostly on Murashige and Skoog (MS) medium (Kumar et al., 2016; Sultana et al., 2016; Seo et al., 2017). Son et al. (2019) reported regeneration of adventitious shoots from callus formed on leaf segments of Hibiscus syriacus.

Cytokinins are known to enhance cell division, cell elongation and induction of shoots from the nodal meristem of explants cultured in vitro (Sami et al., 2016; Wybouw and De Rybel, 2019). 6-Benzyl-aminopurine (BAP) is reported to be the most effective cytokinin for shoot induction, since it can cause proliferation of more axillary buds in a shorter period of time (Bhalla et al., 2009; Bekircan et al., 2018; Faisal et al., 2020) than others. Micropropagation studies of some Hibiscus species, such as Hibiscus sabdariffa, $H$. moscheutos and H. rosa-sinensis showed that the shoot induction response depended on the BAP concentration, plant species and explant type (Kumar et al., 2016; Faisal et al., 2020; Lobodina et al., 2020). For instance, Ayadi et al. (2011) reported a better shoot induction response when Hibiscus cannabinus explants were cultured on media without cytokinins.

An extensive literature review, to the authors' best knowledge, indicated that no other research on in vitro multiplication of $H$. coddii subsp. barnardii has been published before. This study aimed to examine the effect of different factors such as donor plant and explant sources, disinfection treatments and BAP concentrations on the establishment of in vitro shoot culture.

\section{MATERIAL AND METHODS}

\section{Plant material}

The suitability of different in vivo and in vitro grown donor plants as explant source for the establishment of in vitro culture of $H$. coddii subsp. barnardii was studied.

\section{Culture media}

Full strength Murashige and Skoog (MS) basal medium, containing macronutrients, micronutrients, an iron source, vitamins, $3 \%$ sucrose and $0.3 \%(\mathrm{w} / \mathrm{v})$ Gelrite $^{\circledast}$ as solidifying agent (Franklin and Dixon, 1994) was used as a control. For shoot induction experiments, the medium was supplemented with various concentrations of BAP. The medium ( $\mathrm{pH}$ 5.8) was dispensed into Magenta ${ }^{\mathrm{TM}} \mathrm{B}$-cap glass culture vessels and autoclaved at $121^{\circ} \mathrm{C}$ for $20 \mathrm{~min}$.

\section{Explant source and disinfection}

Plants occurring naturally, as well as propagated in vivo from seeds in pots filled with a soil mixture and grown under controlled conditions $\left(24^{\circ} \mathrm{C} \pm 2^{\circ} \mathrm{C}\right.$ with a $16 \mathrm{~h}$ photoperiod at $150-200 \mu \mathrm{mol} \mathrm{m}^{-2} \mathrm{~s}^{-1}$ ), were used as explants sources. Axillary shoot cuttings (100-150 mm) from both types of donor plants were washed in soapy water and thoroughly rinsed with tap water. Surface disinfection was performed with $70 \%$ ethanol for $60 \mathrm{~s}$ followed by immersion in commercial bleach $\left(\mathrm{Jik}^{\circledR}\right)$ solution, either for $25 \mathrm{~min}$ in $25 \%$ solution $[0.875 \%(\mathrm{w} / \mathrm{v}) \mathrm{NaOCl}]$ or for $15 \mathrm{~min}$ in $50 \%$ solution $[1.75 \%(\mathrm{w} / \mathrm{v}) \mathrm{NaOCl}]$. After each disinfection step, cuttings were rinsed three times with sterile distilled water. The cuttings were further trimmed to explants with two to four nodes and inoculated on PGR-free MS medium (one explant per culture vessel). The contaminated cultures and surviving explants were recorded weekly for three weeks.

Aseptic seedlings (5-6 weeks old) derived from chemically scarified and disinfected (Du Plessis et al., 2020) seeds germinated on PGR-free MS medium were also used to obtain aseptic shoot explants that did not require disinfection. Seedlings were aseptically transferred to a Petri dish lined with sterile distilled water to prevent wilting, and the roots were removed. The remaining main shoot ( $\pm 8-10$ nodes) was split into an upper (with apex) and lower part (with cotyledon node and piece of hypocotyl), and are referred to as apical and basal seedling shoot explants, respectively. Explants obtained from the aseptic seedlings were selected for further studying factors affecting shoot multiplication, since they were suitable for establishing contamination-free in vitro cultures.

\section{Explant size and position of inoculation}

Apical and basal seedling shoot explants of different sizes, large (3-4 nodes) and small (1-2 nodes) were inoculated on PGR-free MS medium either in a vertical or horizontal position.

\section{Explant type and BAP concentrations}

A pilot study with large basal seedling shoot explants showed that high concentrations $\left(2,3\right.$ and $\left.4 \mathrm{mg} \mathrm{L}^{-1}\right)$ of 
BAP suppressed shoot proliferation. Hence, the effect of lower concentrations $\left(0.25-1 \mathrm{mg} \mathrm{L}^{-1}\right)$ of BAP on in vitro responses of both apical and basal seedling shoot explants was studied. MS medium without BAP served as a control. Ten replicates were used for each treatment, with one explant per culture vessel, which were arranged randomly in the growth room. For all treatments, the number of explants with sprouted axillary buds, proliferated shoots, roots and callus formation and their survival were recorded over a period of four weeks. Data was analysed with the SPSS Version 26 statistical software package. The crosstabulation procedure was used to form $\mathrm{RxC}$ frequency tables. Pearson's chi-square test (at the 5\% level of significance) was performed to test for associations between explant type and BAP treatments and the various variables. Proliferated primary axillary shoots were subcultured to MS medium with and without BAP.

\section{Growth conditions}

All in vitro cultures were kept under controlled conditions at $24 \pm 2{ }^{\circ} \mathrm{C}$ with a $16-\mathrm{h}$ photoperiod at $55-60 \mu \mathrm{mol} \mathrm{m} \mathrm{m}^{-2} \mathrm{~s}^{-1}$ provided by cool-white fluorescent tubes. Acclimatization was performed at $24{ }^{\circ} \mathrm{C} \pm 2{ }^{\circ} \mathrm{C}$ with a 16 -h photoperiod and a higher light intensity of $150-200 \mu \mathrm{mol} \mathrm{m} \mathrm{m}^{-2} \mathrm{~s}^{-1}$. In vitro regenerated plantlets were removed from the culture vessels and the excess MS medium was washed from the roots with tapwater. Plantlets were transplanted into pots filled with moist vermiculite and covered with perforated transparent plastic bags for the first two weeks to maintain adequate humidity. Bags were completely removed after 2-3 weeks and plants were transferred to a mixture of potting soil, vermiculite and sand [5:3:1 (v/v/v)] and kept for a further 1-2 weeks in the growth room. Acclimatized plants were hardened-off in a greenhouse under uncontrolled environmental (light and temperature) conditions. Survival of the plants was monitored for a further 12 weeks.

\section{RESULTS AND DISCUSSION}

Factors affecting the establishment of in vitro shoot culture of $\boldsymbol{H}$. coddii subsp. Barnardii

\section{Explant source and disinfection}

Preliminary studies on surface disinfection of nodal shoot explants obtained from $H$. coddii subsp. barnardii plants collected from nature showed high incidences of bacterial contamination, irrespective of the concentration of the disinfectant and duration of the treatment, although no fungal infection was observed. Disinfection with $70 \%$ ethanol (60 s) followed by treatment with $25 \%$ (v/v) bleach solution for $25 \mathrm{~min}$ and $50 \%(\mathrm{v} / \mathrm{v})$ bleach solution for $15 \mathrm{~min}$ resulted in $85 \%$ and $80 \%$ contamination of in vitro cultures, respectively, and high mortality $(80 \%)$ of the explants. In contrast, Dar et al. (2012) reported 88\% survival and no contamination of nodal explants of $H$. rosa-sinensis collected from an outside garden when surface-disinfected with $50 \%(\mathrm{v} / \mathrm{v})$ Clorox $^{\circledR}[5.25 \%$ (w/v) $\mathrm{NaOCl}]$ bleach solution containing a higher concentration $(2.63 \%)$ of $\mathrm{NaOCl}$. In general, however, microbial contaminations of in vitro cultures are found to occur more readily when the explant source is taken directly from field grown plants (Lobodina et al., 2020). Disinfection of nodal explants is considered to be more difficult since the attachment of the petiole to the stem at an angle creates a V-shaped trough wherein contaminants can be trapped, making it more difficult to sterilize nodal explants with axillary buds (Dar et al., 2012).

Plants of $H$. coddii subsp. barnardii propagated in vivo from seeds under controlled environmental conditions were also used as explant source, since explants derived from physiologically pre-conditioned plants are considered less prone to microbial contamination in in vitro cultures (Davies et al., 2017). Christensen et al. (2008) and Manokari et al. (2016) used pre-conditioned plants of $H$. rosa-sinensis and $H$. sabdariffa grown in pots in a greenhouse as donor plants. Surface disinfection of H. coddii subsp. barnardii nodal shoot explants with $70 \%$ ethanol $(60 \mathrm{~s})$ and $50 \%(\mathrm{v} / \mathrm{v})$ bleach solution containing $1.75 \%$ active $\mathrm{NaOCl}$ for 15 minsubstantially reduced bacterial contamination $(20 \%)$ of cultures when compared to the explants from naturally grown plants $(80 \%)$. This treatment did, however, cause severe bleaching and necrosis of the explants, as well as death of preexisting axillary buds, from the second week onwards, thus resulting in only $15 \%$ explant survival by the third week. Disinfection of explants with a lower concentration $(25 \%)$ of bleach solution for 25 min lightly improved the survival (35\%), although browning of the explants was observed at three weeks of culture. Bhalla et al. (2009) also reported extensive bleaching of some $H$. rosa-sinensis nodal explants when the surface was disinfected with $2.63 \% \mathrm{NaOCl}$ solution prepared from Clorox ${ }^{\circledR}$ bleach. Disinfection with other sterilants [80\% ethanol (20 s) and $0.1 \%$ mercuric chloride $\left(\mathrm{HgCl}_{2}\right)$ solution for $5 \mathrm{~min}$ ] was also detrimental to Lawsonia inermis shoot tip explants, which showed necrosis and died after six days in culture (Shiji and Siril, 2018). Manokari et al. (2016) found low contamination $(2 \%-5 \%)$ of $H$. sabdariffa explants when disinfected with $\mathrm{HgCl}_{2}$ for $3 \frac{1}{2} 2 \mathrm{~min}$, but reported blackening of the explants with five min of disinfection. On the other hand, Christensen et al. (2008) successfully disinfected explants of $H$. rosa-sinensis $(>90 \%$ explants free of visual contamination) with $1 \%-1.5 \% \mathrm{NaOCl}$ for $20 \mathrm{~min}$. These results suggest that the disinfection treatment and the explant survival may vary depending on plant species.

Nodal shoot explants derived from naturally grown and in vivo propagated H.coddii subsp. barnardii plants proved unsuitable as explant source for the establishment of aseptic in vitro cultures due to their sensitivity to the surface disinfection treatment and high mortality of explants. Therefore, in vitro produced seedlings were tested as an aseptic explant source in order to eliminate the harmful effect of the disinfectants. Contamination-free in vitro cultures were established successfully when various types (apical and basal) and sizes (small and large) of aseptic shoot explants from five to six weeks old in vitro grown seedlings were used. In vitro research on certain Hibiscus species was also mostly performed with aseptically in vitro 
grown seedlings (Govinden-Soulange et al., 2009; Ayadi et al., 2011; Kumar et al., 2016; Sultana et al., 2016; Seo et al., 2017).

\section{Explant size and position of inoculation}

Survival of $H$. coddii subsp. barnardii shoot explants cultured on PGR-free medium depended on explant size. Small explants (1-2 nodes) obtained from both the upper (apical) and lower (basal) part of the seedling did not survive after 3-4 weeks in culture and proved not suitable for further shoot multiplication studies. In contrast, a high percentage (90\%) of larger (3-4 nodes) explants remained viable after four weeks in culture and proliferation of axillary shoots was observed. Yildiz (2012) also reported that larger shoot explants have a better survival percentage. Axillary bud sprouting and shoot proliferation occurred on all of the large basal shoot explants after three weeks of culture on PGR-free medium, irrespective of the inoculation position. However, more of the vertically oriented explants $(40 \%)$ rooted than the $15 \%$ rooting observed on horizontal explants. Furthermore, mostly callus formation was observed on horizontally oriented explants $(75 \%$ of explants), whereas $25 \%$ of vertical explants had callus at the base. For further experiments, $H$. coddii subsp. barnardii shoot explants were inoculated in a vertical position. Additional studies are required to optimize the culture of horizontally oriented explants, which could be used as stool shoots, since subsequent subdivision of the explant at each node, after axillary shoot proliferation, could give rise to more plantlets (Davies et al., 2017).

\section{BAP concentration and the type of explant}

Studies of other Hibiscus species reported the use of BAP for in vitro shoot induction, although the response was dependent on species and explant type (Bhalla et al., 2009; Sami et al., 2016; Lobodina et al., 2020). Based on a pilot study (2, 3 and $4 \mathrm{mg}$ L-BAP), the effect of lower BAP concentrations $\left(0.25,0.50,0.75\right.$ and $\left.1 \mathrm{mg} \mathrm{L}^{-1}\right)$ on in vitro shoot induction of apical and basal seedling shoot explants of $H$. coddii subsp. barnardii was researched in order to improve the plant regeneration efficiency (up to $60 \%$ ) attained on PGR-free MS medium.

The chi-square test of independence showed that there was a significant relationship between the BAP treatments, including the control, and axillary bud sprouting, shoot proliferation, rooting and survival of these explants. The responses also varied with explant type (Table 1). Supplementation of the MS medium with $0.25-1 \mathrm{mg} \mathrm{L}^{-1}$ BAP did not improve axillary bud sprouting and shoot proliferation in both apical and basal shoot explants of $H$. coddii subsp. barnardii as compared to the BAP-free (control) MS medium. Basal shoot explants showed the highest bud sprouting frequency $(70 \%-80 \%)$ and shoot proliferation responses (up to $60 \%$ ) in the presence of lower concentrations $\left(0.25\right.$ and $\left.0.50 \mathrm{mg} \mathrm{L}^{-1}\right)$ of BAP. Reduction in bud sprouting and shoot proliferation response on both types of $H$. coddii subsp. barnardii explants occurred with an increase in the BAP concentration to 0.75 and $1 \mathrm{mg} \mathrm{L}^{-1}$ (Table 1). Similarly, nodal shoot explants of $H$. moscheutos cultured on a lower $\left(0.50 \mathrm{mg} \mathrm{L}^{-1}\right)$ BAP concentration formed 4.33 shoots per explant compared to three shoots per explant with a higher $\left(1 \mathrm{mg} \mathrm{L}^{-1}\right)$ BAP concentration (Lobodina et al., 2020). In contrast, the best bud sprout response $(96 \%)$ on nodal explants of $H$. sabdariffa was reported on MS medium supplemented with $1 \mathrm{mg} \mathrm{L}^{-1}$ BAP (Manokari et al., 2016). Further, Sami et al. (2016) reported the highest number of shoots ( 2.5 shoots/explant) on nodal shoot segments of $H$. syriacus on MS medium supplemented with $0.20 \mathrm{mg} \mathrm{L}^{-1}$ BAP as compared to 1.67 shoots per explant on BAP-free medium. These results may suggest that the shoot induction response varies depending on plant species and explant type.

Table 1. In vitro responses of Hibiscus coddii subsp. barnardii shoot explants from seedling origin after four weeks of culture on Murashige and Skoog (MS) medium supplemented with 6-Benzylaminopurine (BAP)*.

\begin{tabular}{|c|c|c|c|c|c|c|c|c|c|c|}
\hline & \multicolumn{10}{|c|}{ Percentage of apical and basal shoot explants with: } \\
\hline & \multicolumn{2}{|c|}{ Sprouted buds } & \multicolumn{2}{|c|}{ Proliferated shoots } & \multicolumn{2}{|c|}{ Adventitious roots } & \multicolumn{2}{|c|}{ Callus formation } & \multicolumn{2}{|c|}{ Survival } \\
\hline & Apical & Basal & Apical $^{1}$ & Basal & Apical & Basal & Apical & Basal & Apical & Basal \\
\hline \multicolumn{11}{|c|}{$\mathrm{BAP}\left(\mathrm{mg} \mathrm{L}^{-1}\right)$} \\
\hline 0.00 & 90 & 100 & 50 & 100 & 30 & 60 & 30 & 40 & 90 & 100 \\
\hline 0.25 & 70 & 80 & 30 & 60 & 0 & 0 & 40 & 70 & 60 & 20 \\
\hline 0.50 & 40 & 70 & 20 & 50 & 0 & 0 & 40 & 80 & 50 & 20 \\
\hline 0.75 & 30 & 60 & 10 & 40 & 0 & 0 & 50 & 80 & 50 & 20 \\
\hline 1.00 & 20 & 60 & 10 & 40 & 0 & 0 & 50 & 90 & 40 & 20 \\
\hline$P_{0.05}^{2}$ & .009 & .213 & .189 & .037 & .012 & .000 & .886 & .119 & .194 & .000 \\
\hline 3 & \multicolumn{2}{|c|}{.001} & \multicolumn{2}{|c|}{.007} & \multicolumn{2}{|c|}{.000} & \multicolumn{2}{|c|}{.202} & \multicolumn{2}{|c|}{.000} \\
\hline
\end{tabular}

${ }^{1}$ Refers to one axillary shoot that proliferated from the sprouted bud at the base of the apical shoot explant; ${ }^{2}$ Values indicate effect on BAP on apical and basal shoot explants separately; ${ }^{3}$ Values indicate the overall effect of BAP; *Pearson's chi-square test performed at the $5 \%$ level of significance. 
Short shoots (3-4) proliferated on basal shoot explants of $H$. coddii subsp. barnardii in the presence of BAP (Figure 1). The length reduced from $\pm 10 \mathrm{~mm}$ to less than $5 \mathrm{~mm}$ when the concentration increased from $0.25 \mathrm{mg} \mathrm{L}^{-1}$ (Figure 1A) to $1 \mathrm{mg} \mathrm{L}^{-1}$ (Figure 1D). The proliferated shoots did not develop further. Similarly, shoot length in $H$. rosa-sinensis cv. Cassiopeia Wind Yellow was reduced to $2 \mathrm{~mm}$ with a higher $(22 \mu \mathrm{M}) \mathrm{BAP}$ concentration when compared to $5 \mathrm{~mm}$ shoots obtained with a lower $(2.2 \mu \mathrm{M})$ concentration (Christensen et al.,
2008). Shoot length in $H$. cannabinus also reduced from $76 \mathrm{~mm}$ on medium with $0.50 \mathrm{mg} \mathrm{L}^{-1}$ BAP to $44 \mathrm{~mm}$ in the presence of $1 \mathrm{mg} \mathrm{L}^{-1}$ BAP (Ayadi et al., 2011). Manokari et al. (2016) also reported a reduction in $H$. sabdariffa shoot length from $26 \mathrm{~mm}$ to $11 \mathrm{~mm}$ with an increasing concentration (1.50-3 $\mathrm{mg} \mathrm{L}^{-1}$ ) of BAP. High concentrations of BAP may cause ethylene production that negatively affects shoot regeneration and elongation by restricting lengthening of internodes (Davies et al., 2017; Miri, 2020).
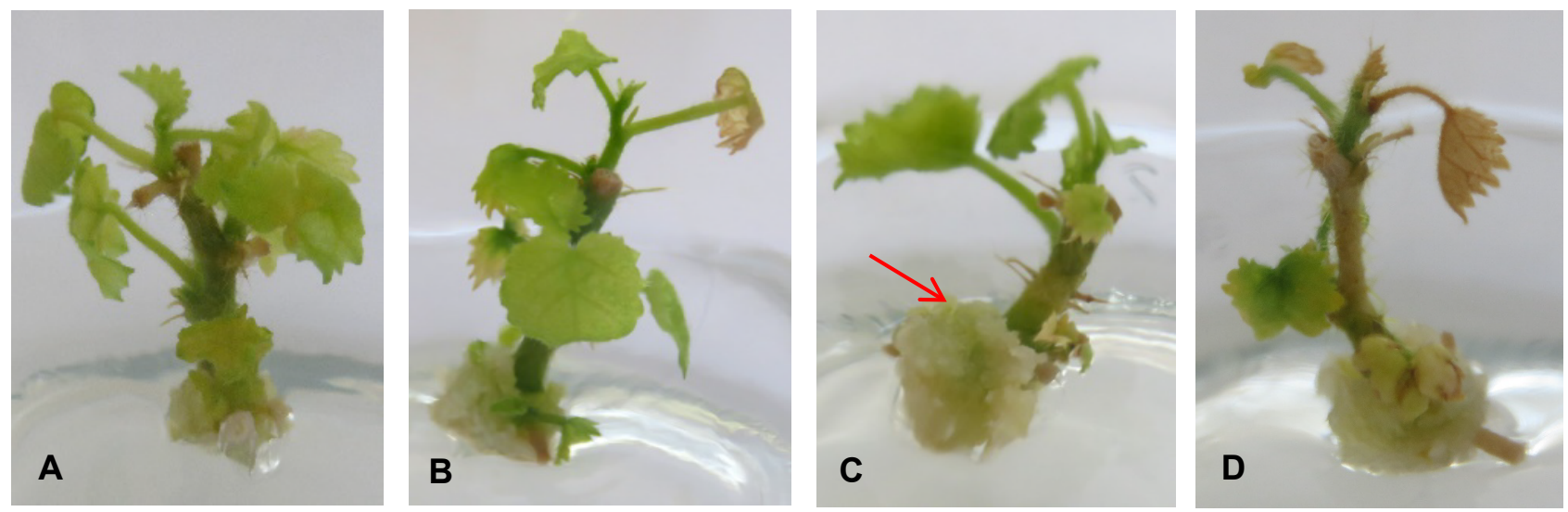

Figure 1. Examples of in vitro shoot proliferation and callus formation on basal seedling shoot explants of Hibiscus coddii subsp. barnardii after 3-4 weeks of culture on MS medium supplemented with 6-Benzylaminopurine (BAP). (A) $0.25 \mathrm{mg} \mathrm{L}^{-1}$; (B) $0.50 \mathrm{mg} \mathrm{L}^{-1}$; (C) $0.75 \mathrm{mg} \mathrm{L}^{-1}$; (D) $1 \mathrm{mg} \mathrm{L}^{-1}$. Callus formation (arrow) on all explants varied from $510 \mathrm{~mm}$ in diameter.

The best bud sprouting and shoot proliferation response in $H$. coddii subsp. barnardii was attained on BAP-free medium (Table 1). Ayadi et al. (2011) also reported a high shoot induction response $(91 \%)$ on seedling nodal explants of $H$. cannabinus cultured on PGR-free medium. In contrast, no shoot induction was reported on nodal explants of $H$. sabdariffa (Manokari et al., 2016) and Rungia pectinata (Shekhawat et al., 2016) cultured on BAP-free medium. In $H$. coddii subsp. barnardii, sprouting (1-2 $\mathrm{mm}$ ) of pre-existing axillary buds (3-5/explant) occurred on $90 \%$ of the apical (Figure $2 \mathrm{~A}$ ) and $100 \%$ of the basal shoot (Figure 2D) explants after one week of culture (Table 1). Further proliferation and elongation of primary axillary shoots were, however, mainly observed on basal shoot explants (Figure 2D) after 3-4 weeks of culture. All the basal shoot explants yielded an average of 3-5 single primary axillary shoots (30-40 $\mathrm{mm}$ in length) per explant (Figure 2G) that could serve as secondary explant source for shoot multiplication and subsequent plant regeneration.
In $60 \%$ of these explants, a clump of short $(5-10 \mathrm{~mm})$ shoots also formed at the base of the explant (Figure $2 \mathrm{G}$ ). Similarly, Govinden-Soulange et al. (2009) obtained the best shoot regeneration response $(81 \%)$ with 3.2 shoots per nodal explant of $H$. sabdariffa. Herath et al. (2004) successfully used the basal part of $H$. cannabinus seedlings as explant for shoot induction, whereas Sultana et al. (2016) reported that $H$. cannabinus hypocotyl explants showed the highest (50\%) shoot regeneration. On apical shoot explants of $H$. coddii subsp. barnardii, only one shoot $(5-10 \mathrm{~mm})$ per explant developed from the sprouted bud at the base of the explants (Figure 2A). The suppression of axillary shoot proliferation observed in these explants could be ascribed to apical dominance exerted by the presence of an apex, as also reported by other studies (Bhalla et al., 2009; Davies et al., 2017). Manokari et al. (2016) also reported poorer bud break and shoot proliferation on apical shoot tip explants of $H$. sabdariffa than on nodal shoot segments, although no data is given. 

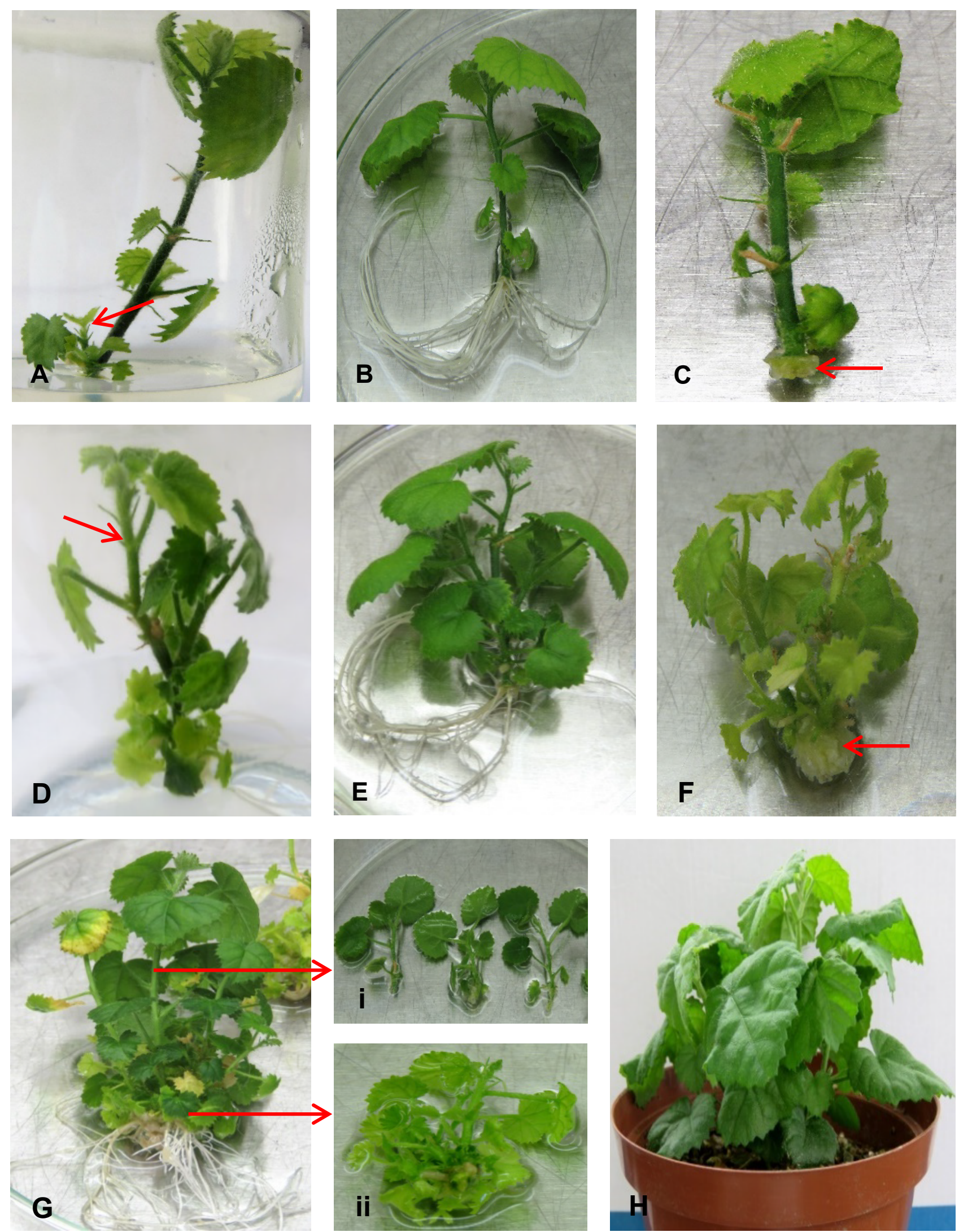

Figure 2. Examples of in vitro responses of Hibiscus coddii subsp. barnardii seedling explants after 3-4 weeks of culture on 6-Benzylaminopurine (BAP)-free MS medium. Apical shoot explants: (A) primary axillary shoot proliferation only at lowest bud sprout (arrow); (B) adventitious roots; (C) callus formation (arrow). Basal shoot explants:

(D) primary axillary shoot proliferation (arrow); (E) adventitious roots; (F) callus formation (arrow); (G) basal shoot explant (five weeks) with (i) long (30-40 mm) shoots; (ii) clump of short (5-10 mm) shoots; $(\mathrm{H})$ acclimatized plant. 
Adventitious root formation had a significant association with the BAP treatment and explant type (Table 1) and was only observed on $H$. coddii subsp. barnardii shoot explants on BAP-free MS medium. Furthermore, $60 \%$ of the basal shoot explants (Figure 2E) rooted, whereas only 30\% of apical shoot explants (Figure 2B) formed adventitious roots after three weeks in culture (Table 1). Ayadi et al. (2011) also reported adventitious root formation on nodal explants of $H$. cannabinus after three weeks of culture on BAP-free medium, although better rooting $(91 \%)$ was attained than in $H$. coddii subsp. barnardii. In plants, endogenous auxin produced by young stem tips and leaves is reported to induce adventitious roots in cuttings (Veraplakorn, 2016; Davies et al., 2017). According to Bhalla et al. (2009), direct root formation on PGR-free medium is ideal for acclimatization in soil, since it eliminates the additional step of root induction with rooting hormones and thereby shortens the plant regeneration process. No root formation was observed on both types of $H$. coddii subsp. barnardii explants on all the BAP treatments (Table 1). In accordance, Manokari et al. (2016) reported no root formation on nodal explants of $H$. sabdariffa in the presence of $0.5-3 \mathrm{mg} \mathrm{L}^{-1}$ BAP. According to Bekircan et al. (2018), adventitious root formation can be inhibited by high cytokinin concentrations. In contrast, Govinden-Soulange et al. (2009) noted simultaneous shoot growth and rooting on nodal explants of $H$. sabdariffa when cultured on MS medium with BAP (0.1-2 $\left.\mathrm{mg} \mathrm{L}^{-1}\right)$. Shoot regeneration from H. coddii subsp. barnardii basal shoot explants correlated with rooting of the explants. Only a few short $(<10 \mathrm{~mm})$ axillary shoots, which started to yellow and subsequently died after four weeks, developed on $H$. coddii subsp. barnardii explants that did not root. Cytokinin produced in roots is reported to stimulate outgrowth of axillary buds and shoots (Waldie and Leyser, 2018).

Callus formation, due to cellular reprogramming of parenchyma cells, is considered a natural response of plant tissue to wounding (Tuskan et al., 2018). Callus formed on both apical and basal shoot explants of $H$. coddii subsp. barnardii that did not root and the frequency increased with an increase in the BAP concentration. The frequency of explants with callus ranged from $40 \%-50 \%$ on apical and $70 \%-90 \%$ on basal shoot explants in the presence of BAP. The highest frequency of callus formation (90\%) was observed on basal shoot explants cultured on MS medium with $1 \mathrm{mg} \mathrm{L}^{-1}$ BAP (Table 1). The formed callus varied from 5-10 $\mathrm{mm}$ in diameter (Figures 1A-1D). Apical and basal shoot explants on the BAP-free medium exhibited the lowest frequency of callus formation, although the callus diameter was smaller on apical shoot explants (Table 1, Figure 2C\&2F). The formed callus was non-generative and prevented shoot proliferation. Manokari et al. (2016) found no callus formation on nodal explants of $H$. sabdariffa cultured on lower concentrations of BAP $\left(0.50\right.$ and $\left.1 \mathrm{mg} \mathrm{L}^{-1}\right)$, but reported a high frequency of callus formation with 2.50 and $3 \mathrm{mg} \mathrm{L}^{-1}$ BAP.

Almost all (90\%-100\%) of the $H$. coddii subsp. barnardii shoot explants in the BAP-free MS medium remained viable, whereas the increase in the BAP concentration adversely affected the viability. Explants on media with the higher BAP concentrations $(0.75$ and $1 \mathrm{mg}$
$\mathrm{L}^{-1}$ ) showed signs of tissue necrosis (browning of explant and leaves) from the third week onwards, which resulted in subsequent death of up to $80 \%$ of explants, respectively (Table 1, Figure 1D). This response might be linked to the excessive callus formation on explants from these BAP treatments that could lead to limited nutrient supply and subsequent death of explants. Faisal et al. (2020) also reported that high cytokinin concentrations stimulated callus growth and decreased the regeneration potential of H. rosa-sinensis explants. More frequent transferring onto fresh MS medium could alleviate the problem (Bhalla et al., 2009; Davies et al., 2017). Manokari et al. (2016) reported that delayed subculturing of more than four weeks resulted in deterioration of $H$. sabdariffa explants. Reduction in survival rate of shoot explants from other Hibiscus species was also associated with higher concentrations of BAP in in vitro cultures. Christensen et al. (2008) reported high survival (95\% and $93.9 \%$ ) of nodal explants of $H$. rosa-sinensis in the presence of lower BAP concentrations ( 0.22 and $2.2 \mu \mathrm{M}$ respectively) that significantly reduced to $65 \%$ with a higher $(22 \mu \mathrm{M})$ BAP concentration. Bhalla et al. (2009) reported a $20 \%$ decrease in the viability of nodal explants of $H$. rosa-sinensis when cultured on MS medium supplemented with 10, 15 and $20 \mu \mathrm{M}$ BAP.

\section{Primary axillary shoot explants}

The axillary shoots produced on rooted basal shoot explants of $H$. coddii subsp. barnardii on PGR-free medium (Figure 2Gi) were also tested as explants for further shoot induction. Sprouting of pre-existing buds was suppressed on explants with an apex, probably due to apical dominance exerted by the apex. Removal of the apex resulted in bud sprouting (3-4 buds/explant) on 100\% of explants on BAP-free medium and on $80 \%$ of explants in the presence of $0.25 \mathrm{mg} \mathrm{L}^{-1}$ BAP after one week of culture. Secondary axillary shoot proliferation (3-4/explant, $15-20 \mathrm{~mm}$ in length) occurred from sprouted buds on $80 \%$ of explants after four weeks of culture only on BAP-free medium. Suppression of bud sprouting was observed with an increasing BAP concentration, as also reported for apical and basal shoot explants obtained from seedlings. No shoot proliferation occurred in the presence of all $(0.25-1.0 \mathrm{mg}$ $\left.\mathrm{L}^{-1}\right)$ concentrations of BAP. Shoot regeneration efficiency in H. cannabinus shoot explants was also negatively affected by an increasing BAP concentration $(4.4,8.8$ and $22 \mu \mathrm{M})$ and reduced from $100 \%$ in BAP-free medium to $56.7 \%$ with $22 \mu \mathrm{M}$ BAP (Herath et al., 2004). This contradicts findings of Christensen et al. (2008), who described the highest number of proliferated secondary axillary shoots (2.2/explant) on primary axillary shoot explants of $H$. rosa-sinensis cv. Cassiopeia Wind Yellow with $2.2 \mu \mathrm{M}$ BAP compared to only 1.1 shoot per explant on BAP-free medium.

Further subculturing of secondary axillary shoots of H. coddii subsp. barnardii onto fresh MS medium (with and without BAP) did not improve shoot multiplication. Tertiary axillary shoots developed on only $20 \%$ of secondary axillary shoot explants on BAP-free medium only after formation of adventitious roots, suggesting low shoot regeneration efficiency. No shoot proliferation was observed 
on explants in the presence of all BAP concentrations (0.25-1.0 $\mathrm{mg} \mathrm{L}^{-1}$ ) and explants died after 3-4 weeks in culture. A shortage or oversupply of nutrients and/or PGRs in the media could be contributing factors to such observations (Christensen et al., 2008; Davies et al., 2017). A decline in the shoot regeneration efficiency with subsequent subculturing of shoots of $H$. rosa-sinensis was also reported by Christensen et al. (2008). In contrast, Ayadi et al. (2011) reported a micropropagation system with five subcultures for $H$. cannabinus, where the maximum number of shoots (3.7 shoots/explant) was reached with the fifth subculture.

Clumps of 4-6 short (5-10 mm) primary axillary shoots that proliferated on basal shoot explants of $H$. coddii subsp. barnardii (Figure 2Gii) increased in length up to 40-50 mm when transferred to BAP-free MS medium only and developed adventitious roots after three weeks in culture. This suggests that the presence of a piece of the initial explant on the clump is beneficial for survival of proliferated axillary shoots and that these clumps can be used for plant regeneration. Similarly, subculturing of sub-divided clumps of $H$. cannabinus on PGR-free medium resulted in shoot elongation and formation of adventitious roots (Srivatanakul et al., 2000).

\section{Acclimatization and hardening-off}

In vitro produced plantlets of $H$. coddii subsp. barnardii were successfully acclimatized over a period of 2-3 weeks in moist vermiculite under controlled conditions (Figure $2 \mathrm{H}$ ). Plants transferred to a mixture of potting soil, vermiculite and sand [5:3:1 (v/v/v)] responded well to hardening-off in a greenhouse, with $80 \%$ survival. Mature plants flowered 2-3 months after the transplant and showed no phenotypic variation.

\section{CONCLUSIONS}

In vitro grown seedlings of $H$. coddii subsp. barnardii proved to be the most suitable aseptic explant source for successful establishment of in vitro shoot culture. The best shoot induction response was attained on basal shoot explants obtained from these seedlings when cultured in a vertical position on BAP-free medium. Further studies are required to optimize the in vitro multiplication of this drought-resistant flowering plant with horticultural potential.

\section{AUTHOR CONTRIBUTION}

HJDP: Experiment conception and design, performing experiments, collection, analysis and interpretation of data, drafting and writing final version of the article. RVN: Advisor of work, experiment conception, interpretation of data, critical revision and approval of final version. RK: Analysis and interpretation of data, critical review and approval of final version of the article. BAE: Critical review of article and approval of final version.

\section{ACKNOWLEDGEMENTS}

We thank the National Research Foundation of South Africa (NRF Grant no: 110867) and the University of Limpopo for financial and research support. We acknowledge Mr. M. Netshidzivhani for his assistance with the statistical analysis.

\section{REFERENCES}

AYADI, R.; HAMROUNI, L.; HANANA, M.; BOUZID, S.; TRIFI, M.; KHOUJA, M.L. In vitro propagation and regeneration of an industrial plant kenaf (Hibiscus cannabinus L.). Industrial Crops and Products, v.33, n.2, p.474-480, 2011. https://doi.org/10.1016/j. indcrop. 2010.10 .025

BEKIRCAN, T.; YAŞAR, A.; YILDIRIM, S.; SÖKMEN, M.; SÖKMEN, A. Effect of cytokinins on in vitro multiplication, volatiles composition and rosmarinic acid content of Thymus leucotrichus Hal. shoots. 3 Biotech, v.8, n.180, p.1-9, 2018. https://doi.org/10.1007/s13205-018-1206-2

BHALLA, S.; ABDULLAH, J.O.; SREERAMANAN, S.; KARUTHAN, C. Shoots induction from Hibiscus rosa-sinensis nodal explant using $\mathrm{N}^{6}$-benzylaminopurine (BAP). Research Journal of Agriculture and Biological Sciences, v.5, n.4, p.403-410, 2009.

CHEN, C. Cost analysis of plant micropropagation of Phalaenopsis. Plant Cell Tissue and Organ Culture, v.126, p.167-175, 2016. https://doi.org/10.1007/s11240016-0987-4

CHRISTENSEN, B.; SRISKANDARAJAH, S.; SEREK, M.; MÜLLER, R. In vitro culture of Hibiscus rosa-sinensis L.: Influence of iron, calcium and BAP on establishment and multiplication. Plant CellTissue and Organ Culture, v.93, p.151-161, 2008. https://doi.org/10.1007/s11240-008-9354-4

DAR, C.T.; ABDULLAH, J.O.; NAMASIVAYAM, P.; ROOWI, S.H. Sterilization of Hibiscus rosa-sinensis L. vegetative explants sourced from plants grown in open environment and influences of organic ingredients on in vitro direct regeneration. American Journal of Plant Sciences, v.3, n.6, p.791-798, 2012. https://doi. org/10.4236/ajps.2012.36095

DAVIES, F.T.; GENEVE, R.L.; WILSON, S.B.; HARTMANN, H.T.; KESTER, D.E. Hartmann \& Kester's plant propagation: principles and practices. 9. ed. New York: Pearson Education, 2017. 1024 p.

DEBNATH, S.C.; ARIGUNDAM, U. In vitro propagation strategies of medicinally important berry crop, Lingonberry (Vacciniumvitis-idaea L.). Agronomy, v.10, n.5, p.744, 2020. https://doi.org/10.3390/agronomy10050744

DU PLESSIS, H.J.; KLEYNHANS, R.; NIKOLOVA, R.V.; EGAN, B.A. Factors affecting seed propagation of Hibiscus coddii subsp. barnardii: a new potential ornamental plant. Propagation of Ornamental Plants, v.19, n.2, p.38-47, 2019. 
DU PLESSIS, H.J.; NIKOLOVA, R.V.; KLEYNHANS, R.; EGAN, B.A. In vitro seed germination and seedling performance of Hibiscus coddii subsp. barnardii. Ornamental Horticulture, v.26, n.4, p.598-606, 2020. http://dx.doi.org/10.1590/2447-536x.v26i4.2191

FAISAL，M.; ALATAR，A.A.; ABDEL-SALAM， E.M.; QAHTAN, A.A. Effects of 4-CPPU on in vitro multiplication and sustainable generation of Hibiscus rosa-sinensis L. 'White Butterfly'. Saudi Journal of Biological Sciences, v.27, n.1, p.412-416, 2020. https://doi.org/10.1016/j.sjbs.2019.11.002

FRANKLIN, C.I.; DIXON, R.A. Initiation and maintenance of callus and cell suspension culture. DIXON, R.A.; GONZALES, R.A. Plant Cell Culture: A practical approach. 2. ed. New York: Oxford University Press Inc., 1994. p.1-23.

GOVINDEN-SOULANGE, J.; BOODIA, N.; DUSSOOA, C.; GUNOWA, R.; DEENSAH, S.; FACKNATH, S.; RAJKOMAR, B. Vegetative propagation and tissue culture regeneration of Hibiscus sabdariffa L. (Roselle). World Journal of Agricultural Science, v.5, n.5, p.651-661, 2009.

HERATH, S.P.; SUZUKI, T.; HATTORI, K. Multiple shoot regeneration from young shoots of kenaf (Hibiscus cannabinus). Plant Cell, Tissue and Organ Culture, v.77, p.49-53, 2004. https://doi.org/10.1023/ B:TICU.0000016497.79856.9a

KUMAR, S.S.; MANOJ, P.; GIRIDHAR, P. Micropropagation for mass multiplication and enriched production of ascorbic acid in tissue culture foliage of roselle (Hibiscus sabdariffa L.). In Vitro Cellular \& Developmental Biology, v.52, p.427-436, 2016. https:// doi.org/10.1007/s11627-016-9785-2

LOBODINA, E; SUPRUN, I.; AL-NAKIB, E.; AVAKIMYAN, A.; TYSCHENKO, E. Micropropagation of hardy Hibiscus (Hibiscus moscheutos L.). BIO Web of Conferences Bioengineering, v.25, p.1-6, 2020. https:// doi.org/10.1051/bioconf/20202505008

MANOKARI, M.; RAVINDRAN, C.P.; SHEKHAWAT, M.S. Optimization of in vitro regeneration in Hibiscus sabdariffa L. An important medicinal plant. World Scientific News, v.34, p.51-62, 2016.

MIRI, S.M. Micropropagation, callus induction and regeneration of ginger (Zingiber officinale Rosc.). Open Agriculture, v.5, n.1, p.75-84, 2020. https://doi. org/10.1515/opag-2020-0008

SAMI, A.M.; HASHISH, KH.I.; SAWSAN, S.S.; LOBNA, S.T. In vitro propagation protocol of Hibiscus syriacus L. plants. International Journal of PharmTech Research, v.9, n.11, p.178-186, 2016.

SEO, S.-G.; RYU, S.-H.; ZHOU, Y.; KIM, S.-H. Development of an efficient protocol for high-frequency regeneration system in Hibiscus syriacus L. Journal of Plant Biotechnology, v.44, n.2, p.164-170, 2017. https:// doi.org/10.5010/JPB.2017.44.2.164

SHEKHAWAT, M.S.; MANOKARI, M.; RAVINDRAN, C.P. Micropropagation, micro-morphological studies, and in vitro flowering in Rungiapectinata L. Scientifica, v.2016, p.1-7, 2016. https://doi.org/10.1155/2016/5813851

SHIJI, P.C.; SIRIL, E.A. An improved micropropagation and ex vitro rooting of a commercially important crop Henna (Lawsonia inermis L.). Physiology and Molecular Biology of Plants, v.24, n.6, p.1273-1284, 2018. https:// doi.org/10.1007/s12298-018-0600-x

SON, J.-H.; SUN, H.-J.; KANG, H.-G.; SUH, S.-C.; LEE, H.-Y. Establishment of an efficient regeneration system for Hibiscus syriacus 'Nanpa'. Journal of Plant Biotechnology, v.46, p.297-302, 2019. https://doi. org/10.5010/JPB.2019.46.4.297

SRIVATANAKUL, M.; PARK, S.H.; SANDERS, J.R.; SALAS, M.G.; SMITH, R.H. 2000. Multiple shoot regeneration of kenaf (Hibiscus cannabinus L.) from a shoot apex culture system. Plant Cell Reports, v.19, p.165-1170, 2000. https://doi.org/10.1007/s002990000256

SULTANA, R.; QUADER, A.K.M.L.; HAQUE, M.; MAZUMDER, S.; PAUL, S.K. In vitro studies on shoot proliferation of kenaf (Hibiscus cannabinus L.). World Journal of Agricultural Sciences, v.12, n.1, p.25-30, 2016. https://doi.org/10.5829/idosi.wjas.2016.12.1.1890

TUSKAN, G.A.; MEWALAL, R.; GUNTER, L.E.; PALLA, K.J.; CARTER, K.; JACOBSON, D.A.; JONES, P.C.; GARCIA, B.J.; WEIGHILL, D.A.; HYATT, P.D.; YANG, Y.; ZHANG, J.; REIS, N.; CHEN, J-G.; MUCHERO, W. Defining the genetic components of callusformation: A GWAS approach. PLoS One, v.13, n.8, e0202519, 2018. https://doi.org/10.1371/journal.pone.0202519

VERAPLAKORN, V. Micropropagation and callus induction of Lantana camara L.-A medicinal plant. Agriculture and Natural Resources, v.50, n.5, p.338-344, 2016. https://doi.org/10.1016/j.anres.2016.12.002

WALDIE, T.; LEYSER, O. Cytokinin targets auxin transport to promote shoot branching. Plant Physiology, v.177, n.2, p.803-818, 2018. https://doi.org/10.1104/pp.17.01691

WYBOUW, B.; RYBEL, B. Cytokinin-A Developing Story. Trends in Plant Science, v.24, n.2, p.177-185, 2019. https://doi.org/10.1016/j.tplants.2018.10.012

YILDIZ, M. The prerequisite of the success in plant tissue culture: high frequency shoot regeneration. LEVA, A.; RINALDI, L.M.R. Recent Advances in Plant in Vitro Culture. Rijeka: IntechOpen, 2012. p.63-90. http://dx.doi. org/10.5772/51097 